\title{
KONSEP KECERDASAN LOGIKA MATEMATIKA BERBASIS BAHAN AJAR PADA KURIKULUM 2013 UNTUK SISWA SEKOLAH DASAR
}

\author{
Eka Farida Fasha ${ }^{1}$, Ujang Khiyarusoleh ${ }^{2}$, M. Khoeril Akhyar ${ }^{3}$ \\ 1efaridafasha@yahoo.co.id, ${ }^{2}$ ujang606bk@gmail.com, \\ odapiss2@gmail.com \\ ${ }^{1}$ Dosen Pendidikan Matematika, ${ }^{2}$ Dosen PGSD, ${ }^{3}$ Dosen Pendidikan Matematika Universitas \\ Peradaban
}

\begin{abstract}
The goal of this research is to know the application of multiple intelligences concept in teaching book on grade IV with the first theme is Indahnya Kebersamaan in curriculum 2013. This research is qualitative descriptive research. While the kind of this research is library research. The object of this research is teaching book on the grade IV with the first theme Indahnya Kebersamaan the first printing in 2013 with 106 pages which arranged and produced by education and culture minister. The variable in this research is multiple intelligences concept. The technique of data collecting in this research uses documentations technique. The research of data is analyzed by content or document analysis and the technique of descriptive analysis that uses presentence technique to know the number and presentence of the contents multiple intelligences concept, not only the whole of intelligences but also each intelligence. The result of this research points that: there is multiple intelligences concept based on Howard Gardner in teaching book on the grade IV with the first theme Indahnya Kebersamaan which can produce and develop each student intelligences. The findings of the data obtained from are as follows. There is a mathematical concept that contains counts of numbers and mathematical symbols as much as $66 \%$. There is a command sentence that shows problem solving activities or counts of $18 \%$. There are math games or other strategy games such as $7 \%$ crosswords, There are sentences that show experimental procedures to find causal relationships. There are sentences that discuss various activities. as much as $6 \%$, rounding up and interpreting statistical data as much as $3 \%$
\end{abstract}

Keywords: Mathematical logic intelligence, Multiple Intelligences, Textbooks, 2013 Curriculum

\begin{abstract}
ABSTRAK
Penelitian ini bertujuan untuk mengetahui aplikasi konsep kecerdasan logika matematika dalam buku ajar kelas IV tema 1 Indahnya Kebersamaan pada kurikulum 2013. Penelitian ini merupakan penelitian deskriptif kualitatif. Sedangkan jenis penelitian ini adalah penelitian kepustakaan atau studi pustaka (library research). Objek penelitian ini adalah buku ajar kelas IV tema 1 Indahnya Kebersamaan cetakan pertama tahun 2013 setebal 106 halaman yang disusun dan diterbitkan oleh kementerian pendidikan dan kebudayaan. Variabel dalam penelitian ini adalah konsep kecerdasan logika matematika. Teknik pengumpulan data menggunakan teknik dokumentasi. Data penelitian dianalisis menggunakan
\end{abstract}


analisis isi atau dokumen (content or document analysis) dan teknik analisis deskriptif menggunakan teknik presentase untuk mengetahui jumlah dan presentase muatan konsep kecerdasan logika matematika, baik secara keseluruhan maupun masing-masing kecerdasan. Hasil penelitian menunjukkan bahwa: terdapat konsep kecerdasan logika matematika menurut Howard Gardner dalam buku ajar kelas IV tema 1 Indahnya Kebersamaan yang dapat menumbuhkan dan mengembangkan masing-masing potensi peserta didik. Temuan data yang diperoleh dari adalah sebagai berikut. Terdapat konsep matematika yang berisi tentang hitungan angka-angka dan simbol-simbol matematika sebanyak 66\%. Terdapat kalimat perintah yang menunjukkan aktifitas pemecahan masalah atau hitungan sebanyak 18\%, Terdapat permainan matematika atau permainan strategi lainnya seperti teka-teki silang sebanyak $7 \%$, Terdapat kalimat yang menunjukkan prosedur percobaan untuk mencari hubungan sebab akibat Terdapat kalimat yang membahas bermacam-macam kegiatan memperkirakan sebanyak 6\%, membulatkan, dan menafsirkan datadata statistik sebanyak 3\%.

Kata kunci: Kecerdasan logika matematika, Multiple Intelligences, Buku Ajar, Kurikulum 2013

\section{PENDAHULUAN}

Kurikulum yang sedang diimplementasikan di Indonesia adalah kurikulum 2013. Pada tahap awal yaitu tahun ajaran 2013/2014, kurikulum 2013 baru diimplementasikan di kelas I dan IV sekolah dasar, kelas VII sekolah menengah tingkat pertama, dan kelas X pada sekolah menengah tingkat atas. Konsep kurikulum 2013 merupakan langkah lanjutan pengembangan kurikulum berbasis kompetensi yang telah dirintis pada tahun 2004 dan KTSP pada tahun 2006. Kompetensi yang dikembangkan meliputi kompetensi sikap, pengetahuan, dan keterampilan. Kurikulum 2013 didesain untuk mencapai visi pendidikan tahun 2025 yaitu menciptakan insan indonesia yang cerdas dan kompetitif. Cerdas di sini adalah cerdas komprehensif, yaitu cerdas spiritual dan cerdas sosial/emosional dalam ranah sikap, cerdas intelektual dalam ranah pengetahuan, serta cerdas kinestetis dalam ranah keterampilan (Kemendikbud, 2013:81). Sejalan dengan peran kurikulum dalam pencapaian visi pendidikan tahun 2025 tersebut, munculnya kurikulum 2013 ini juga diharapkan mampu menghapus paradigma tradisional dunia pendidikan tentang makna kecerdasan.

Howard Gardner (Faruq, 2010:1) menegaskan bahwa ada delapan macam kecerdasan yang dimiliki oleh manusia. Macam-macam kecerdasan ini dikenal dengan istilah kecerdasan majemuk atau dalam bahasa asing disebut multiple intelligences. Konsep multiple intelligences mencakup delapan kecerdasan. Pertama, kecerdasan linguistik yaitu kecerdasan yang berhubungan dengan kemampuan dalam bahasa lisan maupun tulisan. Kedua, kecerdasan logis-matematis yaitu kecerdasan yang berhubungan dengan kekritisan dalam berpikir logis dan angka-angka. Ketiga, kecerdasan visual-spasial yang berhubungan dengan kesukaan seseorang terhadap gambar, presentasi, maupun video. Keempat, 
kecerdasan musikal yang berhubungan erat dengan suara, atau musik. Kelima, kecerdasan kinestetik yang berhubungan dengan kemampuan bergerak. Keenam, kecerdasan interpersonal yaitu kecerdasan dalam bersosialisasi dengan orang lain. Ketujuh, kecerdasan intrapersonal yaitu kemampuan bekerja mandiri dan memiliki rasa percaya diri yang tinggi. Kedelapan, kecerdasan naturalistikyaitu kecerdasan yang berhubungan dengan alam.Setiap anak telah memiliki delapan kecerdasan tersebut sebagai modal untuk meraih kesuksesan dalam hidupnya(Faruq, 2010:2).Hal ini bisa terjadi jika kecerdasan anak menjadi dominan.Delapan kecerdasan yang telah ada dalam diri setiap anak dapat menjadi dominan ketika mendapatkan pembelajaran yang sesuai.

Pembelajaran pada kurikulum 2013 pada jenjang sekolah dasar adalah tematik integratif. Sutirjo dan Sri astuti mamik (Mulyoto, 2013:118) menjelaskan bahwa pembelajaran tematik integratif adalah pembelajaran yang menggabungkan beberapa mata pelajaran dalam satu tema pembahasan. Satu tema pembahasan yang terdiri dari berbagai macam mata pelajaran mencerminkan adanya konsep multiple intelligences yang diaplikasikan. Misalnya bahasa Indonesia didesain untuk mengembangkan kecerdasan linguistik, matematika didesain untuk mengembangkan kecerdasan logis-matematis, SBDP didesain untuk mengembangkan kecerdasan visual-spasial dan kecerdasan musikal, PJOK didesain untuk mengembangkan kecerdasan kinestetik, IPA didesain untuk mengembangkan kecerdasan naturalistik, Pkn didesain untuk mengembangkan kecerdasan intrapersonal, dan IPS didesainuntuk mengembagkan kecerdasan interpersonal.

Pembelajaran tematik memiliki dasar pemikiran bahwa sebaik-baiknya peserta didik belajar adalah apabila belajar itu penuh makna, sebuah tema adalah konsep yang menyatukan berbagai disiplin dan materi pelajaran (Hoerr, 2007:95). Pembelajaran tematik integratif di SD berpedoman pada buku ajar seri tematik terpadu yang telah dipersiapkan oleh pemerintah dalam rangka impelementasi kurikulum 2013. Pengembangan buku ajar pada kurikulum 2013 ini berdasarkan pada beberapa prinsip yang sesuai dengan konsep multiple intelligences, salah satu prinsip pengembangannya adalah berpusat pada potensi, perkembangan, kebutuhan, dan kepentingan peserta didik serta lingkunganya (Kemendikbud, 2013:87). Selain itu, buku ajar ini disusun berdasarkan kompetensi yang diharapkan dari seorang lulusan SD/MI yaitu memiliki kemampuan pikir dan tindak yang produktif dan kreatif dalam ranah abstrak dan konkret yang diperjelas dalam kompetensi inti.

Salah satu kompetensi intinya adalah menyajikan pengetahuan dalam bahasa yang jelas, logis dan sistematis, dalam karya yang estetis, atau dalam tindakanyang mencerminkan perilaku anak sehat, beriman, berakhlak mulia. Buku ajar pada kurikulum 2013 merupakan sebuah komponen kurikulum yang sangat unik karena buku ajar dalam 
kurikulum 2013 merupakan satu-satunya buku ajar tematik terpadu yang wajib digunakan sebagai pedoman KBM. Selain itu, buku ajar ini mengacu pada kurikulum berbasis kompetensi sehingga memuat rencana pembelajaran berbasis aktivitas dan di dalamnya memuat urutan pembelajaran yang dinyatakan dalam kegiatan-kegiatan yang harus dilakukan peserta didik bersama guru untuk mencapai kompetensi tertentu, dan bukan buku yang materinya hanya dibaca, diisi, atau dihafal saja.

Buku ajar pada kurikulum 2013 pada jenjang sekolah dasar memiliki keunikan lain karena berupa buku seri pembelajaran tematik terpadu atau disusun secara tematik dengan cara mengintegrasikan beberapa kompetensi dasar (KD) dari berbagai mata pelajaran. Kompetensi dasar mata pelajaran yang diintegrasikan dalam buku ajar pada kelas I adalah kompetensi dasar mata pelajaran Pendidikan Pancasila dan Kewarganegaraan, Bahasa Indonesia, Matematika, Seni Budaya Dan Prakarya (SBDP), dan Pendidikan Jasmani, Olahraga dan Kesehatan (PJOK). Sedangkan pada kelas IV bertambah dua kompetensi dasar lagi yaitu IPA dan IPS.

Fakta-fakta tentang buku ajar tersebut menggambarkan dengan jelas bahwa buku ajar sebagai komponen kurikulum 2013 memiliki kedudukan penting yaitu sebagai bentuk praktis dari kurikulum 2013 yang mengaplikasikan konsep kecerdasan logika matematika dalam multiple intelligences dan merupakan pedoman dalam kegiatan belajar mengajar terutama di tingkat sekolah dasar (SD)

\section{METODE PENELITIAN}

Jenis metode penelitian yang digunakan merupakan penelitian pengembangan atau dikenal dengan R\&D (research and development). Tahapan penelitian dalam penelitian ini adalah melalui tahap-tahap sebagai berikut:

1. Tahap studi pendahuluan

Tahap pertama peneliti melakukan studi pustaka dan wawancara tidak terstruktur dengan guru dan kelapa sekolah di SD yang akan di teliti, tujuannya adalah untuk mempersiapan produk yang akan dikembangkan.

\section{Tahap perencanaan}

Dalam tahap ini yaitu merencankan penelitian yang berkaitan dengan waktu penelitian selama satu tahun dan pembiayaan penelitian yang dikelurakan.

3. Tahap Penyusunan Draf Produk bahan Ajar

Tahap ini dilakukan analisis tugas. Analisis tugas merupakan langkah-langkah yang dilakukan untuk menentukkan langkah-langkah perencanaan, pelaksanaan, dan penilaian model bahan ajar berbasis multiple intelegence. 


\section{Tahap Validasi Produk I}

Draf model bahan ajar yang sudah di susun untuk selanjutnya di nilai oleh ahli materi, teman sejawat dan guru sebagai pelaku pembelajaran di SD.

Hasil tersebut berkaitan dengan hasil penilaian kelayakan produk dan saran untuk kemudian dijadikan informasi sebagai bahan revisi pada tahap selanjutnya.

5. Tahap Revisi II

Tahap revisi II produk dilakukan setelah diberikan penilaian kelayakan oleh validator.

6. Tahap Kajian Produk Akhir

Tahap ini menetapkan kelayakan dan kevalidan produk yang dikembangkan. Tahap kajian akhir merupakan kegiatan konfirmasi dari hasil kajian teori, kajian penelitian yang relevan dan hasil-hasil penelitian yang diperoleh.

7. Tahap Diseminasi

Tahap diseminasi merupakan kegiatan penyebarluasan produk yang telah dihasilkan agar dimanfaatkan oleh pihak-pihak terkait. Diseminasi dapat dilakukan melalui seminar ilmiah, jurnal, buku ajar, dan workshop

Lokasi penelitiannya adalah berada di wilayah Kabupaten Brebes wilayah selatan Jawa Tengah yaitu Sekolah dasar yang menjadi SD Binaan dan menjadi percontohan dalam penerapan kurikulum 2013 di 5 SD se Brebes Selatan. Variabel dalam penelitian ini adalah konsep multiple intelligences. Sedangkan objek penelitian ini adalah buku ajar kelas IV tema 1 Indahnya Kebersamaan. Teknik pengumpulan data pada penelitian ini menggunakan teknik dokumentasi yaitu teknik pengumpulan data dengan dokumen yang berupa tulisan (catatan) dan gambar. Langkah-langkah pengumpulan data yang ditempuh dalam penelitian ini meliputi hal-hal sebagai berikut: (1) Mempersiapkan rumusan masalah yaitu "Bagaimana aplikasi konsep kecerdasan logika matematika dalam buku ajar kelas IV tema 1 indahnya kebersamaan pada kurikulum 2013"; (2) Membuat indikator konsep kecerdasan logika matematika dalam buku ajar dan kemudian menyusun instrumen dari indikator tersebut; (3) Membaca dan memahami secara berulang-ulang isi buku ajar kelas IV tema 1 indahnya kebersamaan; (4) Mendokumentasikan temuan dengan cara menuliskannya pada instrument penelitian secara obyektif; (5) Menganalisis konsep multiple intelligences yaitu mengurai, membandingkan, memilah data yang mengandung konsep kecerdasan logika matematika yang terkandung dalam setiap materi pada buku ajar kelas IV tema 1 indahnya kebersamaan untuk digolongkan dan dikelompokkan kembali menurut indikator kemudian dicari hubungannya untuk ditafsirkan maknanya dengan bantuan instrument yang telah disiapkan; (6) Setelah sebagian data terkumpul, peneliti harus selalu melakukan pengujian keabsahan 
data penelitian dengan dosen pembimbing; (7) Setelah semua data terkumpul, peneliti menguji semua data yang diperoleh dengan dosen pembimbing. (8) Menyimpulkan hasil analisis konsep kecerdasan logika matematika yang ada di dalam setiap materi pada buku ajar kelas IV tema 1 Indahnya Kebersamaan

\section{HASIL DAN PEMBAHASAN}

Aplikasi konsep kecerdasan logis-matematis dalam buku ajar tema 1 Indahnya Kebersamaan dapat teridentifikasi melalui lima indikator yang telah ditetapkan sebelumnya yaitu berupa:

1. Konsep matematika yang berisi tentang hitungan angka-angka dan simbol-simbol matematika.

2. Kalimat perintah yang menunjukkan aktifitas pemecahan masalah atau hitungan.

3. Permainan matematika atau permainan strategi lainnya seperti teka-teki silang.

4. Kalimat yang menunjukkan prosedur percobaan untuk mencari hubungan sebab akibat.

5. Kalimat yang membahas bermacam-macam kegiatan memperkirakan, membulatkan, dan menafsirkan data-data statistik.

Penulis memperoleh temuan data konsep kecerdasan logis-matematis berupa kalimat perintah, kalimat pertanyaan, dan juga teks bacaan. Datanya adalah sebagai berikut:

\begin{tabular}{|c|c|}
\hline Sub-Variabel & Indikator Kecerdasan Logis-Matematis \\
\hline \multirow{5}{*}{$\begin{array}{c}\text { Kecerdasan Logis- } \\
\text { Matematis }\end{array}$} & $\begin{array}{l}\text { Terdapat konsep matematika yang berisi tentang hitungan angka- } \\
\text { angka dan simbol-simbol matematika. }\end{array}$ \\
\hline & $\begin{array}{l}\text { Terdapat kalimat perintah yang menunjukkan aktifitas pemecahan } \\
\text { masalah atau hitungan. }\end{array}$ \\
\hline & $\begin{array}{l}\text { Terdapat permainan matematika atau permainan strategi lainnya } \\
\text { seperti teka-teki silang. }\end{array}$ \\
\hline & $\begin{array}{l}\text { Terdapat kalimat yang menunjukkan prosedur percobaan untuk } \\
\text { mencari hubungan sebab akibat. }\end{array}$ \\
\hline & $\begin{array}{l}\text { Terdapat kalimat yang membahas bermacam-macam kegiatan } \\
\text { memperkirakan, membulatkan, dan menafsirkan data-data statistik. }\end{array}$ \\
\hline
\end{tabular}

Tabel 01.

Konsep Kecerdasan Logis-Matematis dalam Buku Ajar Kelas IV Tema 1 Indahnya Kebersamaan

Penjabaran secara rinci konsep kecerdasan logis-matematis dalam buku ajar kelas IV tema 1 Indahnya Kebersamaan adalah sebagai berikut: 
Pertama, indikator 1 yaitu terdapat konsep matematika yang berisi tentang hitungan angka-angka dan simbol-simbol matematika. Kalimat-kalimat yang termasuk dalam indikator ini sejumlah 71 kalimat atau $66 \%$.

Berikut adalah beberapa contohnya:

Halaman 4:

"Jumlah anak tangga rumah Lontik biasanya berjumlah ganjil" (halaman 4)

Konsep kecerdasan logis-matematis dalam kalimat tersebut terlihat pada anak tangga rumah Lontik yang berjumlah ganjil, yaitu lawan dari bilangan genap. Dengan konsep kecerdasan ini peserta didik diharapkan dapat mengetahui dan membedakan bilangan ganjil dan bilangan genap.

Halaman 11:

"Temukan sudut lancip, tumpul, dan siku-siku pada kedua rumah adat tadi dengan cara melingkari dan memberi nama tiap sudutnya!" (halaman 11)

Konsep kecerdasan logis-matematis dalam kutipan di atas terlihat karena peserta didik diperintahkan untuk menemukan sudut lancip, tumpul, dan siku-siku pada kedua rumah adat yang telah mereka amati sebelumnya. Sudut merupakan simbol matematika yang berupa dua sinar garis yang memiliki titik pangkal yang sama. Dengan konsep kecerdasan ini diharapkan peserta didik dapat menemukan dan membedakan macam-macam sudut.

Halaman 18:

"Arena bermainnya merupakan kotak persegi panjang dan dibagi menjadi beberapa bagian secara horizontal" (halaman 18)

Konsep kecerdasan logis-matematis yang terlihat pada kutipan di atas adalah karena karena permainan yang digunakan berbentuk kotak persegi panjang yang merupakan salah satu simbol matematika berupa bangun datar dua dimensi yang dibentuk oleh dua pasang rusuk yang masing-masing sama panjang dan sejajar dengan pasangannya, dan memiliki empat buah sudut yang kesemuanya adalah sudut siku-siku. Dengan konsep kecerdasan ini, peserta didik diharapkan dapat mengerti tentang konsep bangun datar berupa persegi panjang yang digunakan sebagai arena permainan serta peserta didik dapat menyebutkan sudut-sudut pada bangun datar persegi panjang tersebut.

Halaman 30:

"Potonglah tali kasur sepanjang $\mathbf{2}$ sampai $\mathbf{3}$ meter." (halaman 30 ) 
Konsep kecerdasan logis-matematis terlihat pada kalimat di atas adalah kegiatan memotong tali kasur dengan mengukurnya sepanjang 2 sampai 3 meter. Dengan konsep kecerdasan ini peserta didik diharapkan dapat mengetahui bahwa meter merupakan satuan panjang, serta dapat memotong tali kasur sesuai ukuran yang ditetapkan dengan memanfaatkan alat pengukuran yang tepat seperti penggaris atau meteran.

Halaman 34:

"Berilah tanda $\sqrt{ }$ untuk bangun yang merupakan segi banyak dan bukan segi
banyak." (halaman 34)

Konsep kecerdasan logis-matematis terlihat pada kalimat di atas adalah peserta didik diperintahkan untuk memberi tanda $\sqrt{ }$ pada bangun yang merupakan segi banyak dan bukan segi banyak. Segi banyak merupakan suatu kurva tertutup yang terdiri atas banyak garis. Dengan konsep kecerdasan ini peserta didik diharapkan mampu membedakan antara bangun segi banyak dan bukan segi banyak.

Halaman 45:

"Sebutkan bentuk-bentuk geometri apa yang kamu amati tadi!" (halaman 45)

Konsep kecerdasan logis-matematis yang terlihat pada kalimat di atas adalah peserta didik diperintahkan untuk menyebutkan bentuk-bentuk geometri yaitu cabang matematika yang berkaitan dengan bentuk, ukuran, dan posisi setelah melakukan kegiatan pengamatan. Dengan konsep kecerdasan ini peserta didik diharapkan dapat menyebutkan bentuk-bentuk geometri sesuai dengan kegiatan pengamatan yang telah mereka lakukan.

Halaman 45:

"Caranya dengan menutup permukaannya sehingga tidak saling tindih dan tidak terdapat celah. Proses tersebut disebut pengubinan." (halaman 45)

Konsep kecerdasan logis-matematis yang terlihat pada kalimat di atas terlihat karena pengubinan adalah proses menutup suatu permukaan dengan suatu bangun datar sedemikian hingga tidak saling tindih dan tidak terdapat celah. Dengan konsep kecerdasan ini peserta didik diharapkan dapat membuat pengubinan yang tepat.

Kedua, indikator 2 yaitu terdapat kalimat perintah yang menunjukkan aktifitas pemecahan masalah atau hitungan. Kalimat-kalimat yang termasuk dalam indikator ini sejumlah 8 kalimat atau $7 \%$. Berikut adalah beberapa contohnya:

Halaman 35:

"Tunjukkan sudut pada segi banyak berikut dan hitunglah besar sudutnya dengan menggunakan busur!" (halaman 35) 
Konsep kecerdasan logis-matematis pada kalimat perintah di atas terlihat karena peserta didik diminta untuk menunjukkan sudut pada segi banyak dan kemudian memanfaatkan busur untuk menghitung besar sudut yang telah ditemukan tersebut. Dengan konsep kecerdasan ini peserta didik diharapkan mampu menggunakan busur dengan benar untuk menghitung besar sudut pada segi banyak yang telah ditentukan.

Halaman 64:

\begin{aligned} \hline "Jadi, berapa kira-kira pulau yang belum diberi nama? Bagaimana ya cara \\ menghitungnya?" (halaman 64) \end{aligned}

Kalimat pertanyaan di atas mengandung konsep kecerdasan logis-matematis karena peserta didik diperintahkan untuk menaksir jumlah pulau yang belum diberi nama dan peserta didik harus bisa menjelaskan cara menghitungnya. Dengan kalimat tanya tersebut, peserta didik dapat berlatih cara menaksir jumlah benda.

Halaman 71:

"Hitunglah pembulatan harga keseluruhan!" (halaman 71)

Kalimat perintah di atas mengandung konsep kecerdasan logis-matematis karena peserta didik diperintahkan untuk menghitung jumlah harga keseluruhan dengan cara membulatkannya. Dengan kalimat perintah di atas, peserta didik dapat menghitung harga dengan cara membulatkan seluruh harga tersebut. Kegiatan membulatkan harga ini merupakan salah satu kegiatan penghitungan yang melibatkan cara berpikir kritis.

Ketiga, indikator 3 yaitu terdapat permainan matematika atau permainan strategi lainnya seperti teka-teki silang. Kalimat-kalimat yang termasuk dalam indikator ini sejumlah 3 kalimat atau 3\%. Berikut adalah beberapa contohnya:

Halaman 69:

"Setelah kamu mengenal berbagai budaya di Indonesia, sekarang saatnya kita bermain Teka-teki Silang Budaya" (halaman 69)

Konsep kecerdasan logis-matematis yang terlihat pada kalimat di atas adalah peserta didik bermain teka-teki silang tentang materi berbagai budaya di Indonesia. Teka-teki silang merupakan permainan kata yang memerlukan strategi dan pemikiran logis.

Halaman 70:

"Sekarang buatlah soal teka-teki silang hasil karyamu sendiri tentang kebudayaan yang telah kamu ketahui. Buatlah di kolom yang telah disediakan." (halaman 70 ) 
Konsep kecerdasan logis-matematis yang terlihat pada kalimat di atas adalah peserta didik diperintahkan untuk membuat soal teka-teki silang hasil karya mereka sendiri tentang materi kebudayaan yang telah mereka ketahui. Dengan membuat soal teka-teki silang, peserta didik dapat berpikir logis dan penuh strategi dalam memilih soal serta menghitung kotakkotak yang harus disediakan untuk penulisan jawaban.

Keempat, indikator 4 yaitu terdapat kalimat yang menunjukkan prosedur percobaan untuk mencari hubungan sebab akibat. Kalimat-kalimat yang termasuk dalam indikator ini sejumlah 6 kalimat atau 6\%. Berikut adalah beberapa contohnya:

Halaman 29:

"Alat: Selang plastik (panjang 2 meter atau lebih).

Langkah kerja:

1. Pegang salah satu ujung selang dan minta temanmu memegang ujung lainnya.

2. Dekatkan ujung selang ke telinga.

3. Minta temanmu berbicara melalui ujung selang yang ia pegang.

4. Dengarkan dan catat apa yang ia sampaikan. Berikan hasilnya kepada temanmu untuk diperiksa."(halaman 29)

Konsep kecerdasan logis-matematis yang terdapat pada prosedur percobaan tentang bunyi diatas terlihat karena prosedur percobaan tersebut dapat menguji coba dan membuktikan sebab akibat sampainya bunyi ke telinga. Kegiatam percobaan ini melatih penalaran serta proses berpikir logis peserta didik.

Halaman 80:

"Percobaan Tinggi Rendah Nada

1. Ambil 8 botol kaca (sama ukuran)!

2. Isilah setiap botol dengan jumlah air yang berbeda! Botol ke-1: $2,5 \mathrm{~cm}$ Botol ke-2: $5 \mathrm{~cm}$ dan seterusnya

3. Tiuplah ujung botol sehingga menghasilkan bunyi!"(halaman 80)

Konsep kecerdasan logis-matematis yang terdapat pada prosedur percobaan tentang bunyi diatas terlihat karena prosedur percobaan tersebut dapat menguji coba dan membuktikan sebab akibat timbulnya tinggi rendahnya nada. Dengan kegiatan percobaan ini, peserta didik dapat berlatih berpikir logis dan membuktikan kebenaran pikirannya.

Kelima, indikator 5 yaitu terdapat kalimat yang membahas bermacam-macam kegiatan memperkirakan, membulatkan, dan menafsirkan data-data statistik. Kalimat-kalimat yang termasuk dalam indikator ini sejumlah 19 kalimat atau $18 \%$. Berikut adalah beberapa contohnya:

\section{Halaman 64:}

"Jika angka satuan tersebut kurang dari 5 , yaitu 1, 2, 3, 4, bilangan dibulatkan ke bawah (dihilangkan). Contoh: 14 Bilangan satuannya adalah 4, yang berarti kurang dari 5 . Oleh karena itu, bilangan 14 dibulatkan ke bawah menjadi 10. Jadi, 14 dibulatkan menjadi 10." (halaman 64) 
Konsep kecerdasan logis-matematis dalam kalimat di atas terlihat karena kalimat tersebut mengajarkan pada peserta didik tentang cara membulatkan bilangan, yaitu dengan mengurangi cacah bilangan namun nilainya hampir sama. Hasil yang diperoleh menjadi kurang akurat, tetapi akan lebih mudah digunakan.

Halaman 66:

"Lakukan pembulatan jumlah uang yang akan dibayarkan Siti jika ia membeli vas bunga, keranjang, dan kipas" (halaman 66)

Konsep kecerdasan logis-matematis pada kalimat perintah di atas terlihat karena peserta didik diminta untuk melakukan pembulatan jumlah uang yang akan dibayarkan siti jika ia membeli vas bunga, keranjang, dan kipas. Dengan kalimat perintah di atas, peserta didik diharapkan mampu menghitung pembulatan dari harga-harga barang yang dibeli Siti. Selain itu, peserta didik juga diharapkan dapat mempraktikkan kegiatan pembulatan tersebut dalam kehidupan sehari-hari.

Halaman 81:

"Taksirlah dengan cepat banyaknya kue khas Indonesia berikut ini!" (halaman 81)

Konsep kecerdasan logis-matematis pada kalimat di atas terlihat karena kalimat tersebut memerintahkan peserta didik untuk memperkirakan jumlah kue khas Indonesia yang terdapat pada gambar dengan membulatkan jumlah kue tersebut. Kegiatan memperkirakan jumlah kue merupakan kegiatan menghitung sekaligus berpikir logis. Konsep kecerdasan logis-matematis dalam buku ajar kelas IV tema 1 Indahnya Kebersamaan berdasarkan perolehan data di atas dapat disajikan dalam bentuk diagram lingkaran (pie chart) sebagai berikut: 


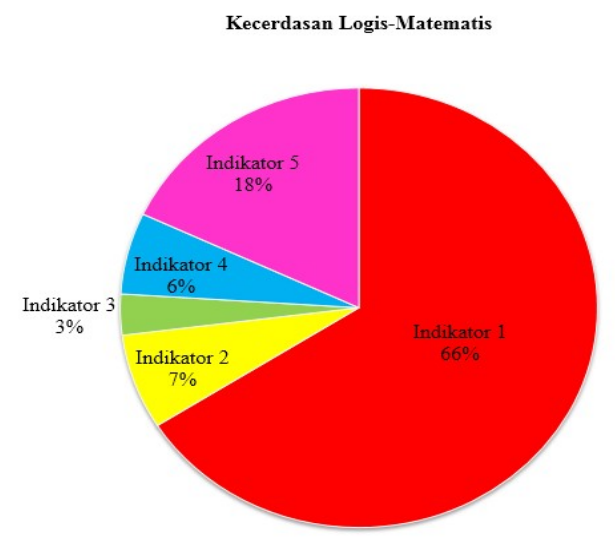

\section{Gambar 01}

Diagram Lingkaran (Pie Chart) Konsep Kecerdasan Logis-matematis dalam Buku Ajar Kelas IV Tema 1 Indahnya Kebersamaan

Diagram di atas dapat menjelaskan temuan konsep kecerdasan logis-matematis dalam buku ajar kelas IV tema 1 indahnya kebersamaan yang diperoleh penulis adalah sebagai berikut:

1. Muatan konsep matematika yang berisi tentang hitungan angka-angka dan simbolsimbol matematika sebanyak $66 \%$, maka peserta didik akan menikmati kegiatan berhitung dan mampu melakukan hal lain dengan angka-angka serta simbol-simbol matematika.

2. Muatan kalimat yang membahas bermacam-macam keterampilan matematis seperti memperkirakan, membulatkan, dan menafsirkan data-data statistic sebanyak $18 \%$, maka peserta didik sedikit trampil dalam memperkirakan, membulatkan, dan menafsirkan data-data statistik.

3. Muatan kalimat perintah yang menunjukkan aktifitas pemecahan masalah atau hitungan sebanyak $7 \%$, maka peserta didik akan sedikit terbiasa dalam melakukan pemecahan masalah dan berhitung.

4. Muatan kalimat yang menunjukkan prosedur percobaan untuk mencari hubungan sebab akibat $6 \%$, maka peserta didik akan mampu mengetahui hubungan sebab akibat dari terjadinya sesuatu.

5. Muatan permainan matematika atau permainan strategi lainnya seperti teka-teki silang sebanyak 3\%, maka peserta didik akan sedikit menikmati permainan matematika. 


\section{KESIMPULAN DAN SARAN}

Temuan data yang diperoleh dari adalah sebagai berikut. Terdapat konsep matematika yang berisi tentang hitungan angka-angka dan simbol-simbol matematika sebanyak $66 \%$. Terdapat kalimat perintah yang menunjukkan aktivitas pemecahan masalah atau hitungan sebanyak $18 \%$, Terdapat permainan matematika atau permainan strategi lainnya seperti teka-teki silang sebanyak $7 \%$, Terdapat kalimat yang menunjukkan prosedur percobaan untuk mencari hubungan sebab akibat Terdapat kalimat yang membahas bermacam-macam kegiatan memperkirakan sebanyak $6 \%$, membulatkan, dan menafsirkan data-data statistik sebanyak $3 \%$

Saran penulis menyarankan kepada peneliti selanjutnya agar mengkaji ulang secara lebih dalam lagi dan mengembangkannya secara lebih luas sampai ke wilayah kekuatan dan kelemahan serta menyimpulkan kualitas buku ajar yang diteliti.

\section{ACUAN PUSTAKA}

Arifin, Samsul dan Adi Kusrianto. (2010). Sukses Menulis Buku Ajar \& Referensi. Jakarta: Grasindo.

Armstrong, Thomas. (2013). Kecerdasan Multipel di dalam Kelas.Penerjemah: Dyah Widya Prabaningrum. Jakarta: Indeks.

Assaraf, John. (2008). Having It All: Rahasia Mencapai Impian.Penerjemah: Susi Purwoko. Jakarta: Gramedia Pustaka Utama.

Faruq, Mohammad Muhyi. (2010). Permainan Kecerdasan Kinestetik Outdoors. Jakarta: Grasindo.

Gichara, Jenny. (2010). Aku Bisa Menjadi yang Kumau. Jakarta: PT Elex Media Komputindo. Hermawan A. Heri, dkk. (2011). Teori Mengajar dalam Ali, M., Ibrahim, R.M Sukmadinata, N.S., Sudjana, D., dan Rasyidin, W., (Penyunting) Ilmu dan Aplikasi Pendidikan. Bandung: IMTIMA (hal. 63-102).

Hoerr, Thomas R. (2007). Buku Kerja Multiple Intelligences: Pengalaman New City Schooldi St. Louis, Missouri, AS, dalam Menghargai Aneka Kecerdasan Anak.Penerjemah: Ary Nilandari.Bandung: Kaifa.

Johnson, Elaine B. (2007). Contextual Teaching and Learning: Menjadikan Kegiatan BelajarMengajar Mengasyikkan dan bermakna. Penerjemah: Ibnu Setiawan. Bandung: Mizan Learning Center.

Kemendikbud. (2013). Materi Pelatihan Guru Implementasi Kurikulum 2013 SD Kelas IV. Jakarta: Badan Pengembangan Sumber Daya Manusia Pendidikan dan Kebudayaan dan Penjaminan Mutu Pendidikan. 
Kemendikbud. (2013). Indahnya Kebersamaan. Jakarta: Kementrian Pendidikan dan Kebudayaan.

Kurniasih, Imas. (2010). Mendidik SQ Anak Menurut Nabi Muhammad Saw. Yogyakarta: Penerbit Pustaka Marwa.

Moleong, Lexi J. (2012). Metodologi Penelitian Kualitatif. Bandung : Remaja Rosdakarya

Mulyoto. (2013). Strategi Pembelajaran di Era Kurikulum 2013. Jakarta: Prestasi Pustaka Jakarta.

Muzamiroh, Mida Latifatul. (2013). Kupas Tuntas Kurikulum 2013: Kelebihan dan Kekurangan Kurikulum 2013. Jakarta: Kata Pena.

Setiono, Widianto. (2009). Apakah Ingin Menemukan Potensi Unggul Anak Anda Sejak Dini?.Jakarta: Grasindo.

Sugihartono, dkk. (2007). Psikologi Pendidikan. Yogyakarta : UNY Press.

Sugiyono. (2012). Metode Penelitian Kuantitatif, Kualitatif dan R\&D. Bandung: Alfabeta.

Suparno, Paul. (2004). Teori Inteligensi Ganda dan Aplikasinya di Sekolah. Yogyakarta: Kanisius.

Prastowo, Andi. (2011). Panduan Kreatif Membuat Bahan Ajar Inovatif. Yogyakarta: Diva Press.

(2013). Pengembangan Bahan Ajar Tematik: Panduang Lengkap Aplikatif. Yogyakarta: Diva Press.

Yudha, Andi. (2010). Kenapa Guru Harus Kreatif. Bandung: Mizan. 